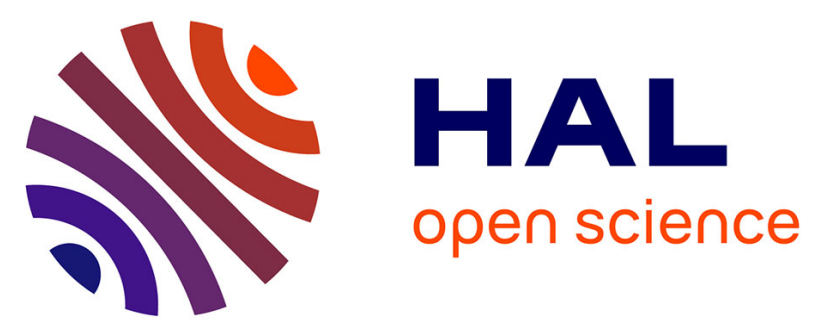

\title{
Implication of the calcium sensing receptor and the Phosphoinositide 3-kinase/Akt pathway in the extracellular calcium-mediated migration of RAW 264.7 osteoclast precursor cells
}

Cédric Boudot, Zuzana Saidak, Abdel Krim Boulanouar, Laurent Petit, Fabrice Gouilleux, Ziad Massy, Michel Brazier, Romuald Mentaverri, Saïd Kamel

\section{- To cite this version:}

Cédric Boudot, Zuzana Saidak, Abdel Krim Boulanouar, Laurent Petit, Fabrice Gouilleux, et al.. Implication of the calcium sensing receptor and the Phosphoinositide 3-kinase/Akt pathway in the extracellular calcium-mediated migration of RAW 264.7 osteoclast precursor cells. BONE, 2010, 46 (5), pp.1416-1423. 10.1016/j.bone.2010.01.383 . hal-03411296

\author{
HAL Id: hal-03411296 \\ https://hal.science/hal-03411296
}

Submitted on 2 Nov 2021

HAL is a multi-disciplinary open access archive for the deposit and dissemination of scientific research documents, whether they are published or not. The documents may come from teaching and research institutions in France or abroad, or from public or private research centers.
L'archive ouverte pluridisciplinaire HAL, est destinée au dépôt et à la diffusion de documents scientifiques de niveau recherche, publiés ou non, émanant des établissements d'enseignement et de recherche français ou étrangers, des laboratoires publics ou privés. 


\title{
Implication of the calcium sensing receptor and the Phosphoinositide 3-kinase/Akt pathway in the extracellular calcium-mediated migration of RAW 264.7 osteoclast precursor cells
}

\author{
Cédric Boudot ${ }^{\mathrm{a}}$, Zuzana Saidak ${ }^{\mathrm{a}}$, Abdel Krim Boulanouar ${ }^{\mathrm{a}}$, Laurent Petit ${ }^{\mathrm{a}}$, Fabrice Gouilleux ${ }^{\mathrm{b}}$, Ziad Massy ${ }^{\mathrm{a}}$, \\ Michel Brazier ${ }^{a}$, Romuald Mentaverri ${ }^{a}{ }^{*}$, Saïd Kamel ${ }^{\text {a }}$ \\ a Institut National de la Santé et de la Recherche Médicale, ERI-12 EA 4292, Université de Picardie Jules Verne, 1 Rue des Louvels, Amiens 80037, France \\ b Génétique, Immmunothérapie, Chimie et Cancer, UMR CNRS 6239, Université François Rabelais de Tours, UFR des Sciences et Techniques, Parc de Grandmont, Tours 37032, France
}

\section{A R T I C L E I N F O}

\section{Article history:}

Received 16 October 2009

Revised 27 January 2010

Accepted 28 January 2010

Available online 10 February 2010

Edited by: Bjorn Olsen

Keywords:

Calcium sensing receptor

Osteoclast precursors

Migration

Extracellular $\mathrm{Ca}^{2+}$

Phosphoinositide 3-kinase

Akt phosphorylation

\begin{abstract}
A B S T R A C T
While the processes involved in the formation, maturation and apoptosis of osteoclasts have been investigated extensively in previous studies, little is known about the mechanisms responsible for the localization and homing of osteoclast precursor cells to the bone environment in order to initiate the bone remodeling process. Recent studies have suggested that the extracellular $\mathrm{Ca}^{2+}\left(\mathrm{Ca}^{2+}{ }_{\mathrm{o}}\right)$ concentration gradient present near the bone environment may be one of the participating factors, producing a chemoattractant effect on osteoclast precursors. Using the murine osteoclast precursor cells of the monocyte-macrophage lineage, the RAW 264.7 cell line, we have shown that $\mathrm{Ca}^{2+}{ }_{0}$ increases the migration of these cells in a directional manner. The participation of the calcium sensing receptor ( $\mathrm{CaR})$ in this effect was tested by knocking down its expression through RNA interference, which resulted in an abolition of the migratory response. By the use of specific pathway inhibitors and western blot analysis, the phosphoinositide 3-kinase $(\mathrm{PI} 3 \mathrm{~K}) /$ Akt and phospholipase $\mathrm{C} \beta$ pathways were shown to be implicated in the migratory effect. The implication of the Akt pathway in the $\mathrm{Ca}^{2+}{ }_{0}$-induced chemoattraction of RAW 264.7 cells was also confirmed by transducing the cells with the fusion protein TAT-dominant negative-Akt, which decreased the migratory effect. In contrast, the MAPK pathways (ERK1/2, p38 and JNK) were not involved in the production of the migratory effect. We conclude that through the activation of the CaR and subsequent signaling via the PI3K/ Akt pathway, $\mathrm{Ca}^{2+}$ o produces a chemoattractant effect on the osteoclast precursor RAW 264.7 cells. These results suggest that the $\mathrm{Ca}^{2+}{ }_{\text {o }}$ gradient present near the bone may be one of the initiating factors for the homing of osteoclast precursors to bone, thus possibly playing a role in the initiation of bone remodeling.
\end{abstract}

(C) 2010 Elsevier Inc. All rights reserved.

\section{Introduction}

Throughout life a continuous process of bone turnover takes place, involving the degradation of old bone and formation of new bone. The bone remodeling process is the result of a collaborative effort of osteoclasts, cells responsible for bone resorption, and osteoblasts, cells in charge of bone formation [1]. These two cell types form temporary anatomical structures, the so-called Basic Multicellular Units (BMUs), which dissolve old bone and replace it with new bone [2]. About 1 million operational BMUs function at any instant in healthy human adults [3,4]. However, the factors underlying BMU initiation are currently not well understood. The first stage of the remodeling process is believed to involve the recruitment of mononucleated osteoclast precursors from the circulation [5]. These cells then

\footnotetext{
* Corresponding author. INSERM, ERI-12, 1, rue des Louvels, Amiens 80037, France. Fax: + 33322827469 .

E-mail address: romuald.mentaverri@sa.u-picardie.fr (R. Mentaverri).
}

infiltrate the bone lining cell layer, followed by the fusion of osteoclast precursors, thus forming multinucleated osteoclasts, capable of resorbing bone [6]. The resorption phase ends with osteoclast apoptosis, which is then followed by bone formation phase, initiated by the recruitment of osteoprogenitor cells to the surface of resorption lacunae [7]. Osteoprogenitor cells are attracted to this environment due to the release of appropriate chemoattractant signals from bone, which then drive the differentiation of these cells to functional osteoblasts involved in bone formation $[8,9]$.

In addition to its important roles in body movement and the protection of internal organs, the skeleton also serves as a reservoir of calcium and phosphorus and other factors. These bone derived products play an important role in directing various cell types to the bone environment. For example, in the case of osteoclast precursor cells, it has previously been described that peripheral blood monocyte cells (PBMC) are chemotactically attracted to resorbed products of the bone matrix $[10,11]$. Furthermore, a previous study by Olszak et al. (2000) has described that $\mathrm{Ca}^{2+}{ }_{\mathrm{o}}$ stimulates the migration of PBMC 
$[12,13]$. Since the concentrations of $\mathrm{Ca}^{2+}{ }_{\mathrm{o}}$ can reach very high levels near resorbing bone (up to $40 \mathrm{mM}$ ) [14,15], it is tempting to speculate that $\mathrm{Ca}^{2+}{ }_{\mathrm{o}}$ is one of the signals that initiates the invasion of bone by circulating osteoclast precursors in order to initiate the formation of a BMU and begin the bone remodeling process. While a number of studies have investigated osteoclast formation, differentiation and apoptosis, very little is known about the mechanisms that lead circulating osteoclast precursor cells to the bone environment to begin bone resorption.

For this reason, in this study we examined the effect of $\mathrm{Ca}^{2+}{ }_{\mathrm{o}}$ on the migration of a well established osteoclast precursor model, the RAW 264.7 cell line. Our results show that increased $\mathrm{Ca}^{2+}{ }_{\mathrm{o}}$ stimulates the migration of osteoclast precursor cells in a concentrationdependent manner. One mechanism by which cells can respond to variations in $\mathrm{Ca}^{2+}{ }_{0}$ concentrations is through the calcium sensing receptor (CaR), a $G$ protein-coupled receptor sensitive to divalent cations, aromatic L-amino acids and aminoglycoside antibiotics [16]. Using RNA interference, we have demonstrated the involvement of the CaR in the migratory effect, and we show that the phosphoinositide 3-kinase (PI3K)/Akt signaling pathway is implicated in the phenomenon. In this work we propose the CaR as a possible candidate for the initiation of the formation of a BMU and the bone remodeling process.

\section{Materials and methods}

\section{Materials}

RAW 264.7 cells were purchased from American Type Culture Collection (ATCC). Dulbecco's modified Eagle's medium (DMEM), phosphate buffered saline (PBS), trypsin-EDTA and penicillin/streptomycin were provided by Sigma, France. GlutaMAX ${ }^{\mathrm{TM}}$ was provided by Invitrogen, France. Wortmannin, U73122, U0126, SB 202190 and SP600125 were purchased from Sigma, France. Bovine serum albumin (BSA), Trypan blue, Giemsa stain, Tween $0.1 \%$ and bromophenol blue were provided by Sigma, France. Nitrocellulose membranes, SDSpolyacrylamide gel (SDS-PAGE), Whatman papers and fetal bovine serum (FBS) were purchased from Dominique Dutscher Laboratories, France. Nuclepore Track-Etched membranes ( $8 \mu \mathrm{m}$ pore) were purchased from Whatman. ECL substrate solution was provided by Amersham Pharmacia Biotech, Orsay, France. The Lowry protein assay was purchased from BIO-RAD. Boyden Chambers and polycarbonate membranes were provided by Neuroprobe, Inc ${ }^{\circledR}$, USA. siPORT NéoFX came from Ambion, France and OPTI-MEM was bought from Gibco, Invitrogen, France. Small interfering RNA (siRNA) directed against CaR and scramble sequences came from Eurogentec, Belgium. Primary mouse anti-CaR antibody was purchased from Bioreagent; rabbit pERK antibody was obtained from Cell Signaling Technology, Boston, MA. Secondary anti-rabbit and anti-mouse peroxidase IgG antibodies were purchased from Sigma, France. Antibodies against P-Akt ${ }^{\mathrm{Ser} 473}$ and Akt came from Cell signaling Technology, Boston, MA. Antibodies against HA came from Roche, Basel, Switzerland. Phycoerythrin (PE) conjugated IgG mouse antibodies were obtained from BD Biosciences, Le pont de Claix, France. BL21 pLysS Escherichia coli came from Stratagene, Amsterdam, Netherlands. Ni-NTA agarose came from Qiagen. All others reagents were purchased from Sigma, France.

\section{Cell culture and stimulation}

Murine RAW 264.7 monocyte-macrophage cells were maintained in DMEM supplemented with 10\% FBS, 2 mM GlutaMAX ${ }^{\mathrm{TM}}$, $100 \mathrm{U} / \mathrm{ml}$ penicillin/streptomycin. Cell viability was assayed using Trypan blue dye exclusion, and was typically greater than $95 \%$. Cultured cells were maintained up to passage 20, and then discarded. Before each experiment, cells were serum starved for at least $4 \mathrm{~h}$ in DMEM containing $0.2 \% \mathrm{BSA}$, preincubated with or without pharmacological inhibitors for $30 \mathrm{~min}$. For western blot analyses, cells were stimulated for the indicated times and concentrations with $\mathrm{Ca}^{2+}$. Stimulation was stopped by aspirating the medium and washing the cells with ice-cold PBS.

\section{Migration assay}

Boyden Chamber cell migration assays were performed using polycarbonate membranes with a pore size of $8 \mu \mathrm{m}$. Serum-free DMEM with different concentrations of $\mathrm{Ca}^{2+}(1.8-20 \mathrm{mM})$ was added to the lower chamber. $5 \times 10^{4}$ RAW 264.7 cells in $500 \mu$ l serum-free DMEM (with or without TAT-Akt proteins) were added to the upper chamber. Cells were allowed to migrate for $5 \mathrm{~h}$ at $37^{\circ} \mathrm{C}$ in an incubator with $5 \% \mathrm{CO}_{2}$. After the incubation period, the upper media were removed, chambers were disassembled and membranes were fixed in $96 \%$ methanol for 2 min. Filters were stained with Giemsa, then rinsed well with water. Cells on the upper side of the membrane were cleaned off with a cotton swab. The cells were then viewed at $20 \times$ magnification under an inverted microscope and counted. To allow for comparison between multiple assays, the data were normalized, and they are expressed as percentage of the number of cells present in the membrane at $1.8 \mathrm{mM}$ $\mathrm{Ca}^{2+}$.

\section{CaR-siRNA transfection}

Cells were grown in a 6-well plate to a confluence of $25 \%$. They were then transiently transfected either with CaR-siRNA or scramblesiRNA (negative control) using $50 \mathrm{nM}$ siRNA in OPTI-MEM medium and the siPORT NéoFX transfection reagent, following the manufacturer's instructions. The mixture was delicately applied to cells. After a $3 \mathrm{~h}$ incubation at $37^{\circ} \mathrm{C}$ in an incubator containing $5 \% \mathrm{CO}_{2}$, the cells received DMEM supplemented with 30\% FBS and they received fresh DMEM with $10 \%$ FBS the next day. Transfected cells were maintained in culture for $24 \mathrm{~h}$ before use.

\section{Preparation of cell lysates and Western blot analysis}

After stimulation, cells were washed once with PBS and lysed with $100 \mu$ lysis buffer (25 mM Tris-HCl, pH 7.6, 150 mM NaCl, 10\% glycerol, $1 \%$ Nonidet P-40, $2 \mathrm{mM} \mathrm{Na}_{3} \mathrm{VO}_{4}$ and cocktail mini-protease inhibitors), placed on ice for $30 \mathrm{~min}$ and then centrifuged at $14,000 \times \mathrm{g}$ for $20 \mathrm{~min}$ at $4{ }^{\circ} \mathrm{C}$. Protein concentrations were measured using the Lowry protein assay. Following SDS-polyacrylamide gel electrophoresis, equal amounts of protein were electrophoretically transferred to protean nitrocellulose membrane. All SDS-polyacrylamide gel electrophoresis were performed under reducing conditions ( $\beta$-mercaptoethanol). Blots were blocked, then probed with antibodies raised against the following proteins: CaR, P-Akt ${ }^{\text {Ser473 }}$, Akt, HA. Immunoblots were developed using appropriate secondary horseradish peroxidase-coupled antibodies before adding ECL substrate solution and exposing to Kodak X-Omat film. To ensure equal loading of proteins from whole extracts, the membranes were stripped by incubating the membrane for $30 \mathrm{~min}$ at $55^{\circ} \mathrm{C}$ in $62.5 \mathrm{mM}$ Tris- $\mathrm{HCl}, \mathrm{pH} 6.7,100 \mathrm{mM} \beta$-mercaptoethanol and $2 \%$ SDS. The blot was then washed twice with $50 \mathrm{mM}$ Tris- $\mathrm{HCl}, \mathrm{pH} 7.5$, $150 \mathrm{mM} \mathrm{NaCl}$ and $0.1 \%$ Tween 20 and reprobed as described above.

\section{Flow cytometry analysis}

$5 \times 10^{5}$ cells were incubated with CaR monoclonal antibodies or with isotype control antibodies for $30 \mathrm{~min}$ on ice in the dark. After washes in PBS-3\% FBS and 0.1\% sodium azide, cells were incubated with PE-conjugated IgG mouse antibodies for $30 \mathrm{~min}$. After several washes, expression of cell surface CaR was analyzed by FACS (FACS Aria cytometer). 


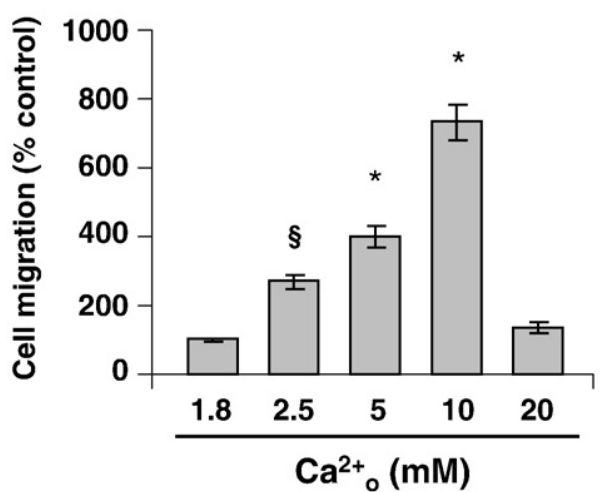

Fig. 1. The effect of $\mathrm{Ca}^{2+}$ o on RAW 264.7 cell migration. The effect of different concentrations of $\mathrm{Ca}^{2+}{ }_{0}(1.8-20 \mathrm{mM})$ on the migration of RAW 264.7 cells was tested in the Boyden Chamber migration assay. $\mathrm{A} \mathrm{Ca}^{2+}{ }_{o}$ concentration-dependent increase in migration of RAW 264.7 cells was observed with a maximal effect at $10 \mathrm{mM} \mathrm{Ca}^{2+}{ }_{0}$. Results from four independent experiments are shown. Data were analyzed by $t$-test analysis, $\S p<0.01$ and ${ }^{*} p<0.001$ control $\left(1.8 \mathrm{mM} \mathrm{Ca}^{2+}{ }_{0}\right)$ vs. migration at increased $\mathrm{Ca}^{2+}{ }_{0}$.

\section{Purification of TAT-Akt fusion proteins}

The cDNAs encoding wild-type (wt) and dominant negative ( $\mathrm{dn}$ )Akt were cloned into pTAT-HA plasmid by C.B. and F.G. as previously described $[17,18]$. Akt fusion proteins were expressed by inducing BL21 pLysS Escherichia coli transformed with plasmids encoding the TAT-Akt fusion proteins with $100 \mu \mathrm{M}$ IPTG for $4 \mathrm{~h}$. Cells were harvested by centrifugation at $4000 \times \mathrm{g}$ for $5 \mathrm{~min}$. The bacterial pellets were resuspended in extraction buffer A (4 M urea, 20 mM HEPES pH 8.0 and $500 \mathrm{mM} \mathrm{NaCl}$ ) followed by sonication. Lysates were clarified by centrifugation and adjusted to $15 \mathrm{mM}$ Imidazole and loaded on a NiNTA agarose column. Afterwards, the resin was washed in buffer A+ $15 \mathrm{mM}$ imidazole and eluted with $250 \mathrm{mM}$ imidazole. The eluate was dialyzed against $\mathrm{PBS}$ overnight at $4{ }^{\circ} \mathrm{C}$. Purified fusion protein concentrations were determined by Coomassie blue staining of SDSPAGE compared to BSA standards.

\section{Statistical analyses}

The results are expressed as the mean $+/$ - the standard error of measurement (S.E.M.) of the indicated number of experiments.
A

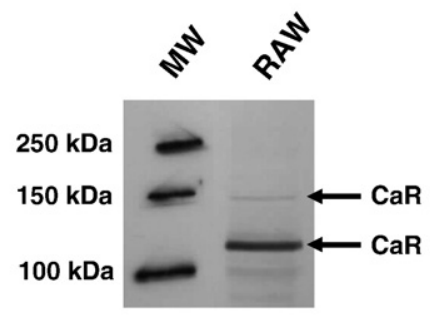

Blot anti-CaR
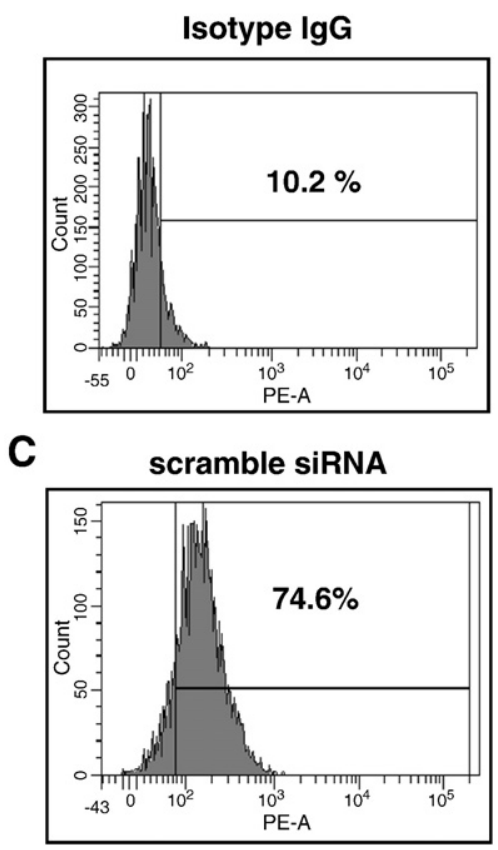

Anti-CaR IgG

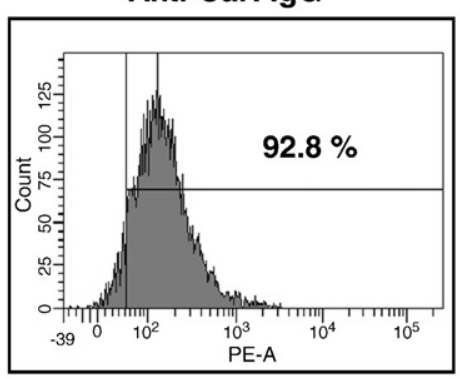

CaR SiRNA

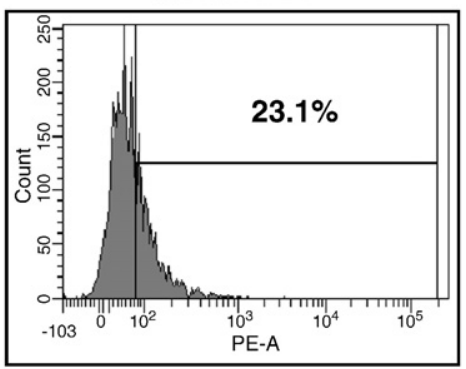

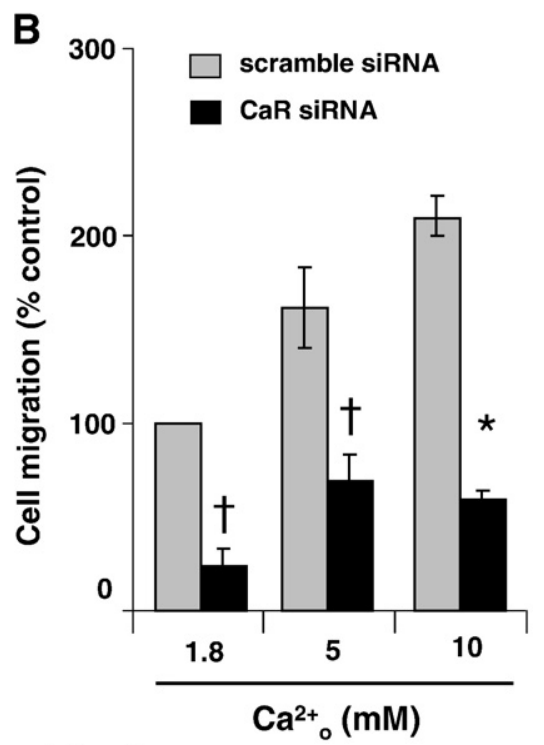

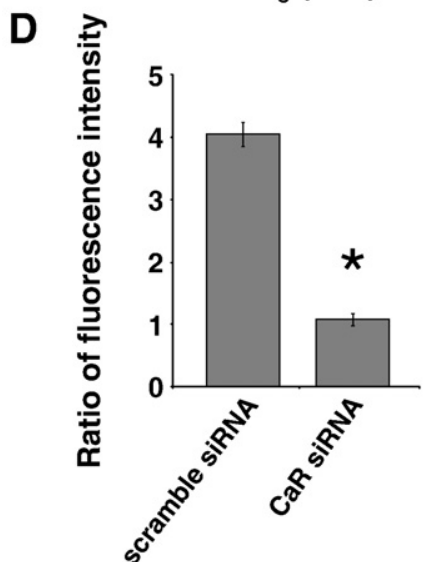

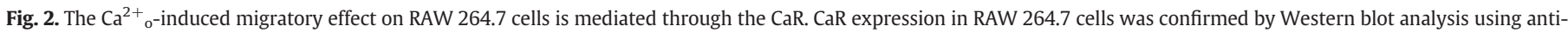

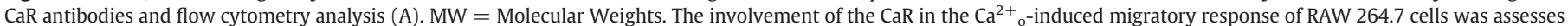

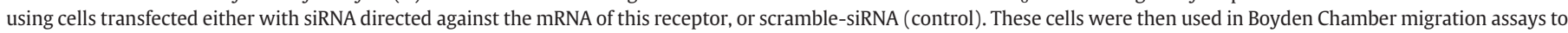

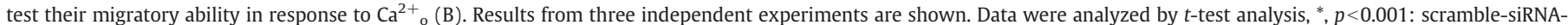

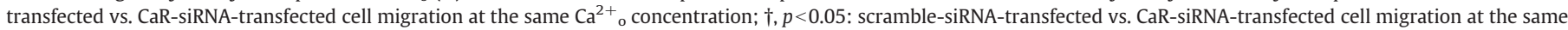

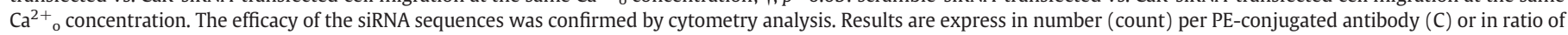
fluorescence intensity (D). ${ }^{*}, p<0.001$ : scramble-siRNA-transfected vs. CaR-siRNA-transfected cell. 
Statistical analyses were performed using Student's $t$-test. A value of $p<0.05$ was considered to be significant.

\section{Results}

Migration of RAW 264.7 cells increases at elevated $\mathrm{Ca}^{2+}{ }_{o}$ concentrations

Since $\mathrm{Ca}^{2+}$ o has previously been described to regulate the migration of different cell types $[12,13,19,20]$, we studied the effects of $\mathrm{Ca}^{2+}{ }_{\text {o }}$ on the migration of RAW 264.7 osteoclast precursor cells. Using the Boyden Chamber assay, we showed that $\mathrm{Ca}^{2+}{ }_{\text {o }}$ strongly stimulates the migration of RAW 264.7 cells in the direction of elevated $\mathrm{Ca}^{2+}{ }_{\text {o }}$ concentrations (Fig. 1). This effect was $\mathrm{Ca}^{2+}{ }_{\text {o }}$ concentrationdependent, with a maximal increase in migration observed at $10 \mathrm{mM}$ $\mathrm{Ca}^{2+}{ }_{\mathrm{o}}$. Higher $\mathrm{Ca}^{2+}{ }_{\mathrm{o}}$ concentrations $(20 \mathrm{mM})$ did not affect the migration of RAW 264.7 cells.

The $\mathrm{Ca}^{2+}{ }_{{ }}$-induced migration of RAW 264.7 cells is mediated through the CaR

Previous studies have reported the role of the $\mathrm{CaR}$ in the migration of various cells $[12,13,19,20]$. Firstly, we have demonstrated that the CaR is expressed in RAW 264.7 cells by Western blot analysis, corresponding to a $120 \mathrm{kDa}$ protein, and cytometry analyses (Fig. 2A), confirming previous reports [21]. Cytometry analysis has demonstrated that cell surface CaR is expressed by $96 \%$ of the cells (Fig. 2A).

Next, to determine whether the $\mathrm{CaR}$ is involved in the $\mathrm{Ca}^{2+}{ }_{\mathrm{o}^{-}}$ induced migration of RAW 264.7 cells, the expression of the CaR was decreased using specific siRNA targeting the CaR or control scramblesiRNA. With CaR-siRNA-transfected cells, the $\mathrm{Ca}^{2+}{ }_{0}$-induced migration was greatly reduced compared to cells transfected with scramblesiRNA (Fig. 2B). These results demonstrate that the $\mathrm{Ca}^{2+}{ }_{\mathrm{o}}$-induced migratory effect is mediated through the activation of the CaR. The functionality of the siRNA sequences utilized in this study was confirmed by cytometry analysis that has demonstrated that while $74.6 \%$ of scramble-siRNA-transfected cells expressed cell surface CaR, only $23.1 \%$ of CaR-siRNA-transfected cells expressed the receptor (Fig. 2C). Moreover, the ratio of receptor expression between CaRsiRNA vs. scramble-siRNA-transfected cells was even greater when total fluorescence intensity was calculated, with receptor expression of around 1:4 (Fig. 2D).

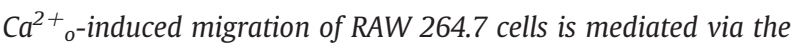
PI3K/Akt pathway

To investigate the intracellular pathways involved in the $\mathrm{Ca}^{2+}{ }_{0}{ }^{-}$ induced migration of RAW 264.7, cells were incubated with $10 \mu \mathrm{M}$ of various specific pathway inhibitors, including inhibitors of PI3K (wortmannin), phospholipase C $\beta$ (PLC $\beta$ ) (U73122) and inhibitors of different MAPKs, ERK1/2 (U0126), p38 (SB 202190) and JNK (SP600125). This was followed by testing cell migration in a Boyden Chamber assay at different concentrations of $\mathrm{Ca}^{2+}{ }_{0}$, as described above. Fig. 3 shows that the $\mathrm{Ca}^{2+}{ }_{0}$-induced migration of RAW 264.7 cells was completely inhibited by wortmannin, demonstrating that the PI3K pathway is involved in the $\mathrm{Ca}^{2+}{ }_{0}$-induced migratory effect. Cell viability after wortmannin treatment remained unchanged compared to control when assessed by Trypan blue exclusion (data not shown). The inhibitor of PLC $\beta$ also dramatically reduced the $\mathrm{Ca}^{2+}{ }_{0}$-induced migratory response (Fig. 4A). This was in contrast to the MAPK pathways, inhibition of which produced no effect on the migratory response mediated by $\mathrm{Ca}^{2+}$ o (Figs. 4 B-D).

One of the known targets of PI3K is the serine-threonine kinase Akt. We studied the activation of Akt in RAW 264.7 cells in response to $\mathrm{Ca}^{2+}{ }_{\mathrm{o}}$ by western blot analysis. $\mathrm{Ca}^{2+}{ }_{\mathrm{o}}$ induced the phosphorylation of Akt in a concentration-dependent manner (Fig. 5A). This effect was maximal after 5 min of stimulation with $\mathrm{Ca}^{2+}{ }_{o}$ and decreased after

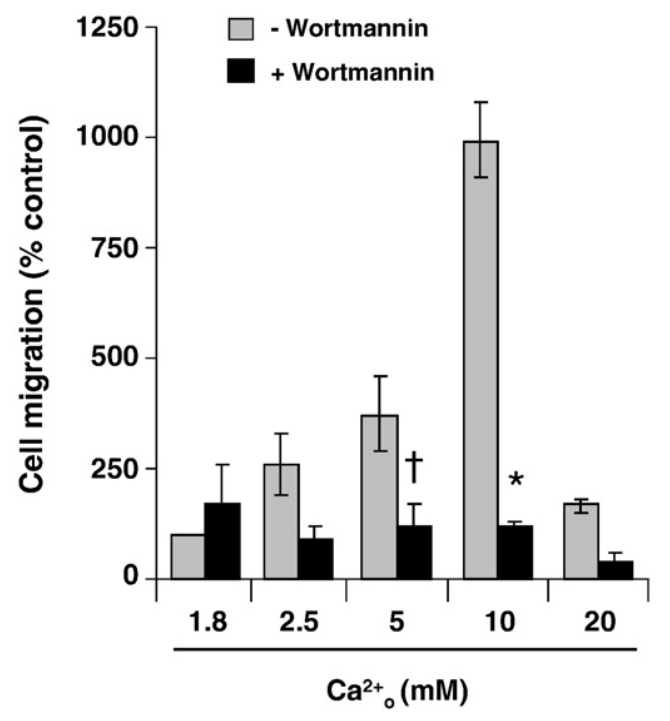

Fig. 3. The PI3K pathway is involved in the $\mathrm{Ca}^{2+}{ }_{\mathrm{o}^{2}}$-induced migratory response of RAW 264.7 cells. RAW 264.7 cells were preincubated with or without the PI3K inhibitor wortmannin $(10 \mu \mathrm{M})$, prior to their use in the Boyden Chamber migration assay, to assess their chemoattraction towards elevated $\mathrm{Ca}^{2+}{ }_{\mathrm{o}}$. Results from three independent experiments are shown. Data were analyzed by $t$-test analysis, ${ }^{*}, p<0.001$ : untreated vs. wortmannin-treated cell migration at the same $\mathrm{Ca}^{2+}{ }_{0}$ concentration; $\dagger, p<0.05$ : untreated vs. wortmannin-treated cell migration at the same $\mathrm{Ca}^{2+}{ }_{\mathrm{o}}$ concentration.

30 min of stimulation (Fig. 5B). The phosphorylation of Akt did not change when cells were stimulated with 10 or $20 \mathrm{mM} \mathrm{Ca}^{2+}{ }_{0}$, suggesting that other molecular mechanisms may be responsible for the modulation of cell migration at high calcium concentrations. The involvement of the $\mathrm{CaR}$ in the $\mathrm{Ca}^{2+}{ }_{0}$-induced Akt activation was confirmed by siRNA directed against this receptor, which abolished Akt activation (Fig. 5C).

To assess the involvement of Akt in RAW 264.7 cell migration, these cells were transduced either with wt-Akt or mutant dn-Akt K179M. To prepare the cell permeable Akt fusion protein, an expression vector expressing Akt as a fusion protein with the protein transduction domain (PTD) of the HIV-1 TAT protein was constructed. Then, different recombinant TAT-Akt fusion proteins were generated (Fig. 6A). A wtor a dn-form of Akt, containing a point mutation inactivating its kinase activity (K179M), was fused to the protein transduction domain of the TAT HIV protein. Proteins TAT-wt-Akt and TAT-dn-Akt were generated and purified by affinity chromatography on a nickel column. The purity of TAT-wt-Akt and TAT-dn-Akt fusion proteins was verified by Coomassie blue stained gel. The purified products were confirmed by western blotting with anti-HA and anti-Akt antibodies (Fig. 6B). Transduction efficiency of the different TAT-Akt proteins in RAW 264.7 cells was evaluated by western blot analysis with anti-Akt and anti-HA antibodies (Fig. 6C). We observed equal transduction of both proteins. The biological effects of the TAT-Akt proteins on the migration of RAW 264.7 cells in response $\mathrm{Ca}^{2+}{ }_{\mathrm{o}}$ were then evaluated. As shown in Fig. 6D, transduction of TAT-dn-Akt completely inhibited cell migration induced by $\mathrm{Ca}^{2+}{ }_{0}$, whereas TAT wt-Akt had no effect. These results demonstrate that Akt plays an important role in RAW 264.7 cell migration in response to $\mathrm{Ca}^{2+}$.

\section{Discussion}

In the parathyroid, the CaR plays a primary role in the regulation of systemic $\mathrm{Ca}^{2+}{ }_{0}$ homeostasis due to its ability to sense minute changes in $\mathrm{Ca}^{2+}$ o concentrations, leading to modulation of parathyroid hormone secretion [22]. Recent data have reported that the CaR is also expressed by other organs and tissues involved in $\mathrm{Ca}^{2+}{ }_{\mathrm{o}}$ homeostasis such as 
A
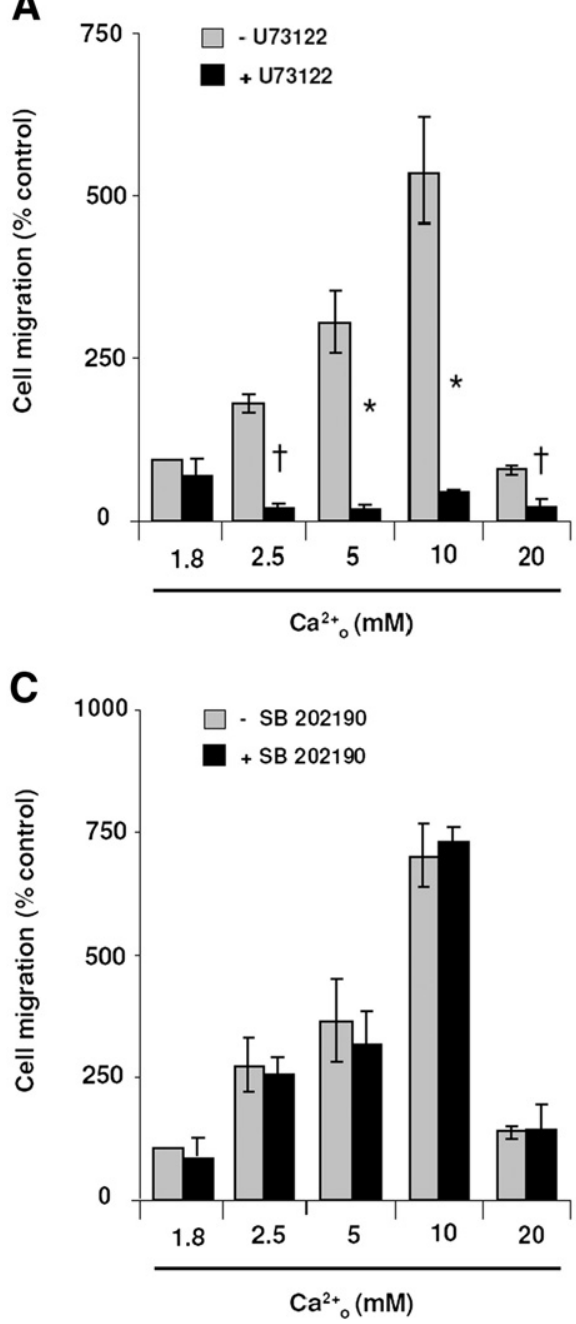

B

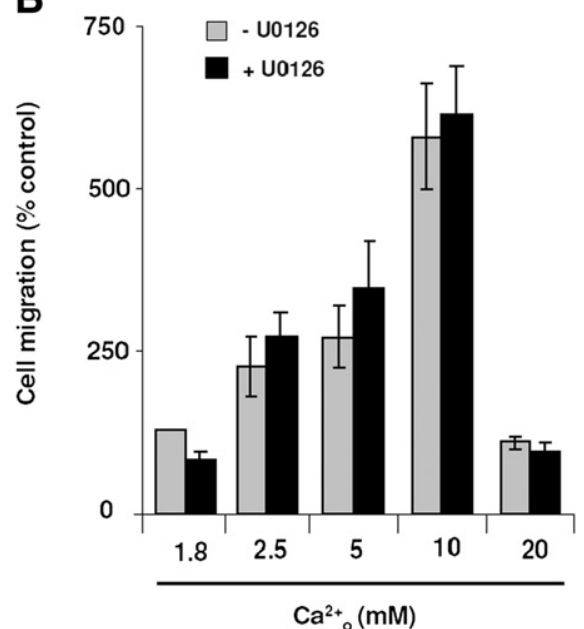

D

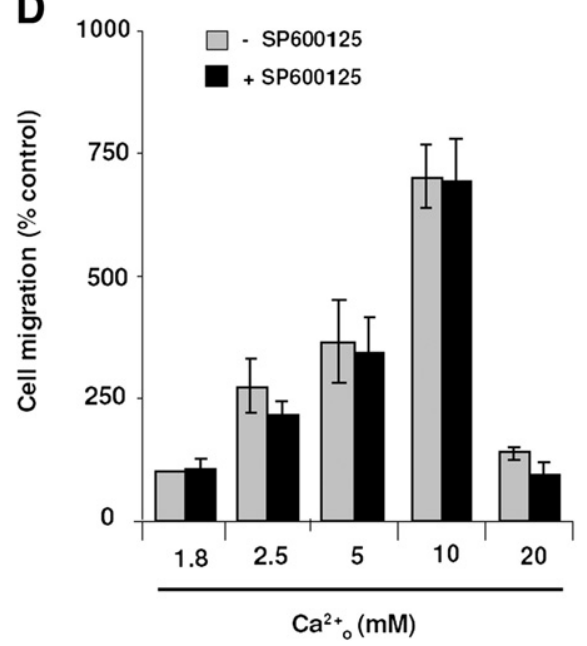

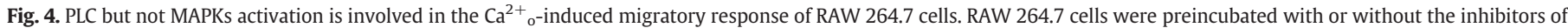

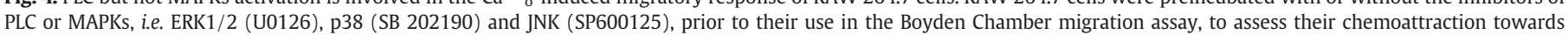

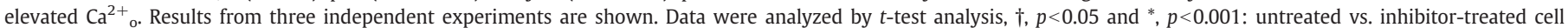
migration at the same $\mathrm{Ca}^{2+}{ }_{\mathrm{o}}$ concentration.

the bone $[23,24]$ and kidneys $[25,26]$, as well as in tissues not involved in $\mathrm{Ca}^{2+}{ }_{\mathrm{o}}$ homeostasis, such as lens epithelial cells and antral gastrin cells of the stomach $[27,28]$. Expression of the CaR has been confirmed in the different cell types present in bone, including the osteoclasts [24], osteoblasts [23] and osteocytes [23] and their precursors [29]. In these cell types, the $\mathrm{CaR}$ is involved in numerous physiological functions, for example osteoclast differentiation and apoptosis [21].

In addition to the previously reported role of the CaR in differentiation, proliferation and apoptosis of bone cells, several recent studies have suggested that this receptor may also play a role in the migration of osteoclast precursor cells, as well as other cells $[12,13,19,20]$. For example, Adams et al. (2006) have demonstrated the involvement of $\mathrm{Ca}^{2+}{ }_{\mathrm{o}}$ and the $\mathrm{CaR}$ in the homing of hematopoietic stem cells to the bone marrow [12]. For this reason, we hypothesized that $\mathrm{Ca}^{2+}$ o and the CaR may play a role in the initiation of the formation of a BMU by recruiting osteoclast precursor cells of the hematopoietic lineage from the circulation to their osseous niches in the bone environment, where high $\mathrm{Ca}^{2+}{ }_{\mathrm{o}}$ concentrations are present as a result of nearby bone resorption. In order to address this issue, we investigated the effect of $\mathrm{Ca}^{2+}{ }_{\text {o }}$ on the migration of RAW 264.7 cells of the monocyte-macrophage lineage using the Boyden Chamber migration assay. We have demonstrated that the migration of the osteoclast precursor RAW 264.7 cells increases with elevated $\mathrm{Ca}^{2+}{ }_{\mathrm{o}}$ concentrations. This effect was shown to require the presence of the $\mathrm{CaR}$, and knocking down CaR expression using siRNA abrogated the $\mathrm{Ca}^{2+}{ }_{0}$-induced migration.

Furthermore, we wanted to decipher the intracellular signaling pathways responsible for the migratory effect. The CaR couples to $\mathrm{G} \alpha_{\mathrm{q}}$ and $\mathrm{G} \alpha_{\mathrm{i}} \mathrm{G}$ proteins, leading to the activation of several intracellular responses, especially PLC $\beta$ [30] and MAPKs [31,32], and inhibition of adenylate cyclase activity [33]. In order to investigate the involvement of these pathways in the migratory effect of RAW 264.7 cells in response to $\mathrm{Ca}^{2+}{ }_{0}$, we have utilized different pathway inhibitors, demonstrating that the PI3K/Akt and PLC 3 pathways are involved in the migratory effect. Next, we addressed the involvement of the Akt, a downstream target of PI3K, in the migration of the RAW 264.7 cells. $\mathrm{Ca}^{2+}{ }_{0}$-induced activation of Akt was demonstrated by western blot analysis and it was shown to be mediated through the CaR. Furthermore, the role of Akt in the migratory effect was shown by transducing the cells with dominant negative TAT-Akt, which decreased the migration of the cells in response to $\mathrm{Ca}^{2+}{ }_{0}$. In contrast, inhibition of the p42/44, p38 and JNK MAPKs did not abolish the $\mathrm{Ca}^{2+}{ }_{\mathrm{o}}$-induced migration of RAW 264.7 cells, suggesting that these pathways are not required for the migratory response. It is not yet clear whether the $\mathrm{CaR}$ present in osteoclasts and osteoclast precursors couples to the MAPKs. While it has been demonstrated that the CaR present in 

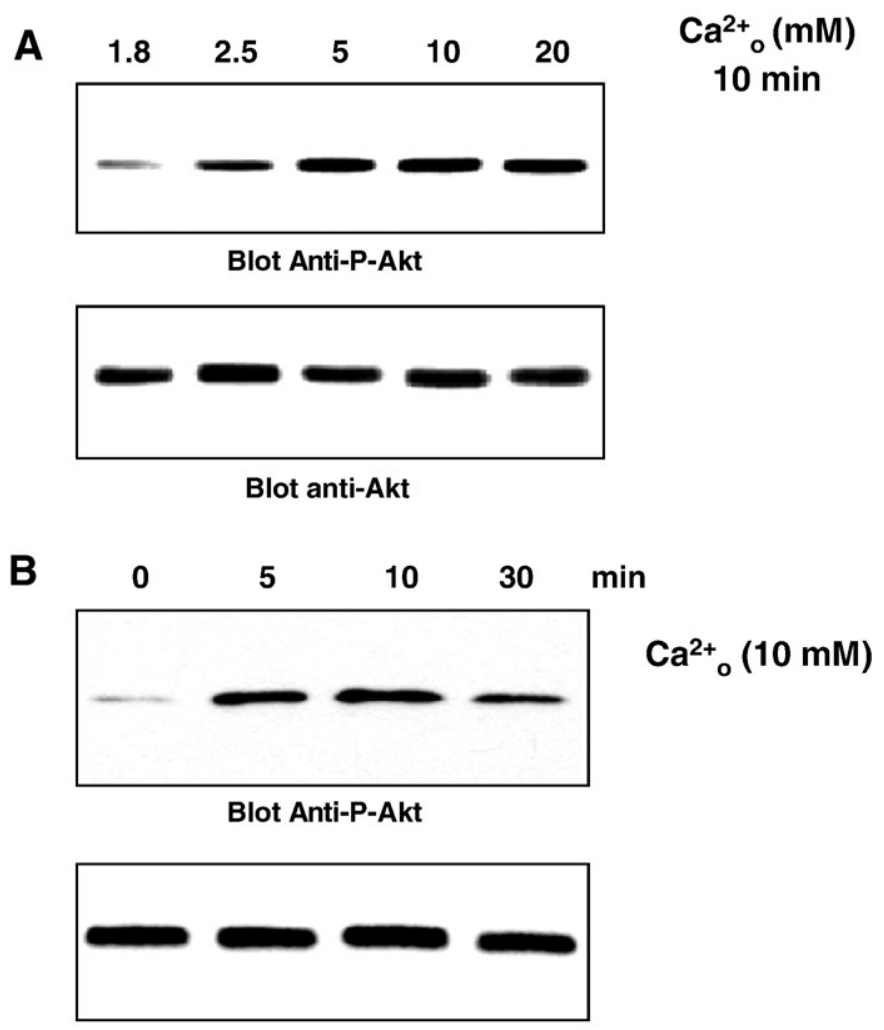

Blot anti-Akt

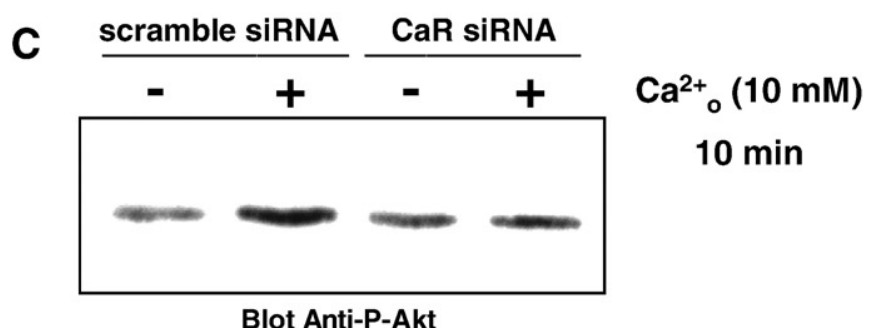

Blot Anti-P-Akt

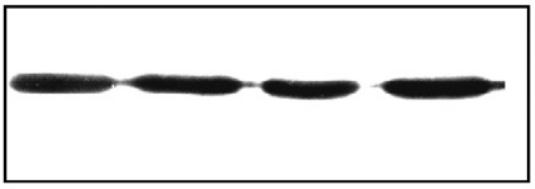

Blot anti-Akt

Fig. 5. $\mathrm{Ca}^{2+}{ }_{0}$-induced Akt phosphorylation is mediated through the CaR. RAW 264.7 cells were stimulated either with different $\mathrm{Ca}^{2+}{ }_{0}$ concentrations $(1.8-10 \mathrm{mM})$ for $10 \mathrm{~min}(\mathrm{~A})$ or with $10 \mathrm{mM} \mathrm{Ca}^{2+}{ }_{\mathrm{o}}$ for 0-30 min (B). Cell lysates were analyzed by SDSPAGE and western blotting using specific antibodies which recognized the phosphorylated form of the Akt (P-Akt). The blots was then stripped and reprobed with anti-Akt antibodies. The involvement of the $\mathrm{CaR}$ in the $\mathrm{Ca}^{2+}{ }_{0}$-induced Akt activation was demonstrated by the use of siRNA directed against the receptor $\left(10 \mathrm{mM} \mathrm{Ca}^{2+}{ }_{0}, 10 \mathrm{~min}\right)$ (C). Data shown are representative of three independent experiments.

osteoblasts does activate p38, p42/44 and JNK [31,32], the intracellular signaling pathways activated via the CaR in osteoclasts require further investigation. However, this study has nevertheless shown that the MAPKs are not involved in the $\mathrm{Ca}^{2+}{ }_{0}$-induced migratory effect, and importantly, we have clearly identified the PI3K/Akt pathway as being pivotal for the $\mathrm{Ca}^{2+}{ }_{\mathrm{o}}$-induced migration of RAW 264.7 cells.

Activation of the PI3K pathway through the CaR has previously been described in different cell types [34,35]. It has been described that cell proliferation is mediated through the activation of this pathway via the CaR [36,37]. Furthermore, Liu et al. (2003) have shown that the $\mathrm{Ca}^{2+}{ }_{0}$-induced secretion of serotonin from parafollicular cells is mediated through the CaR and subsequent activation of PI3K [38]. The involvement of the PI3K pathway in the migratory effect reported in our study is consistent with several recent findings. For example, it has been shown that osteoclasts derived from mice lacking the $\mathrm{p} 85 \alpha$ regulatory subunit of PI3K demonstrate a significantly reduced ability to migrate [39]. Additionally, in a study by Pilkington et al. (1998), the authors have proposed that the directional motility of mature osteoclasts in response to M-CSF is mediated through the PI3K pathway [40], and it has also been reported that the PI3K pathway is involved in the platelet derived growth factor-induced migratory effect $[41,42]$. However, contrasting findings have also been reported, for example Godwin and Soltoff (1997) have shown that $\mathrm{Ca}^{2+}{ }_{\mathrm{o}}$-induced chemotaxis of MC3T3-E1 is mediated through a pertussis-toxin sensitive pathway and is independent of the PI3K pathway, shown by its resistance to wortmannin [41].

A possible source of the local increase in $\mathrm{Ca}^{2+}{ }_{0}$ may originate from bone microdamages, as a result of daily activity. Through bone remodeling, bone cells are able to repair any microdamage, thus contributing to the maintenance of the structural integrity of bone and calcium homeostasis [43]. However, the mechanism by which microcracks are detected, and repair initiated, is not yet understood. Form our data, it can be speculated that microdamage of the bone may result in the release of $\mathrm{Ca}^{2+}{ }_{0}$, stimulating the homing of cells specialised in bone-repair. It is also conceivable that this increase in $\mathrm{Ca}^{2+}{ }_{\mathrm{o}}$ is the result of an initial osteoclast activity which may lead to the recruitment of further osteoclast precursors, whose transformation into osteoclasts is promoted by the CaR [21]. While our study demonstrates that the migration of RAW 264.7 increases in response to elevated $\mathrm{Ca}^{2+}{ }_{\mathrm{o}}$ through the activation of the CaR/PI3K/Akt, thus possibly implicating this pathway in the homing of osteoclast precursor cells to bone and the initiation of the establishment of BMUs, the shortcomings of our study need to be stressed. Whether the CaR plays a pivotal role in the bone remodeling process in a physiological context still needs to be elucidated in future studies. The experimental model used in this study is limited and it is not suitable to address this issue. Therefore, to gain a better understanding of the precise mechanisms involved in the initiation of a functional BMU, a novel experimental approach needs to be developed, that maximally mimics the physiological conditions of the bone.

Interestingly, Garner et al. (2001) have reported that expected skeletal manifestations of PTH excess were not the main skeletal features in CaR knock-out mice, which rather showed growth plate calcification and disorderly deposition of mineral, excessive osteoid accumulation, and prolonged mineralization lag time in metaphyseal bone[44]. Given our results, certain outstanding questions still remain. Does the bone remodeling process take place in these animals? Do the osteoclast precursors in these animals target the correct sites in the bone in order to initiate bone remodeling? For all these reasons, in future investigations it would be very interesting to study the migration of osteoclast precursors derived from the bone marrow of $\mathrm{CaR}^{-1-}$ mice. Our current study aimed to determine certain aspects of the intracellular signaling that takes place upon CaR activation in osteoclast precursor cells and the involvement of these pathways in the $\mathrm{Ca}^{2+}{ }_{0}$-induced chemoattraction. Given the results we obtained on the effects of high concentrations of calcium on the differentiation, bone resorption and apoptosis of osteoclasts, it can be hypothesized that the CaR is involved in the recruitment of osteoclast precursor cells from the circulation during the establishment of a functional BMU [21]. Furthermore, activation of the CaR may also lead to a negative feedback effect at higher concentrations of $\mathrm{Ca}^{2+}{ }_{0}$, released from bone during the bone resorption process. It is possible that the $\mathrm{CaR}$ is also involved in the infiltration of these cells through the bone lining cell layer and fusion of these cells into functional 
A

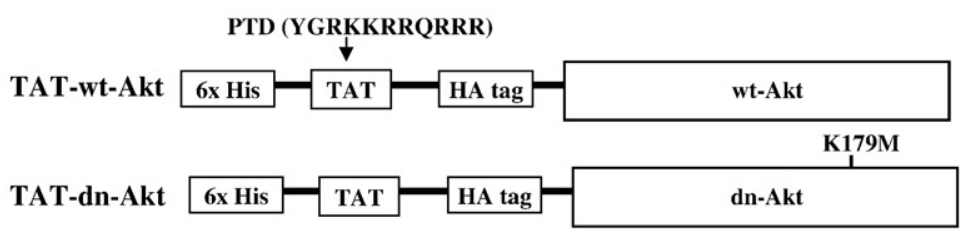

B

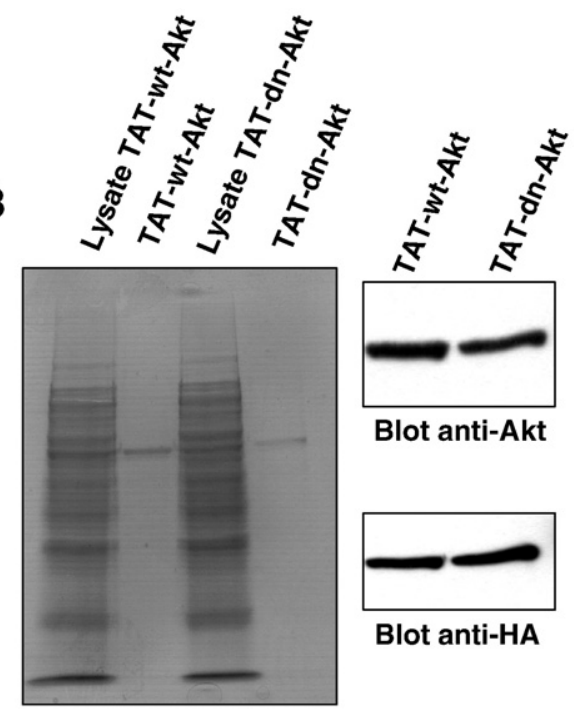

Blot anti-Akt

Blot anti-HA

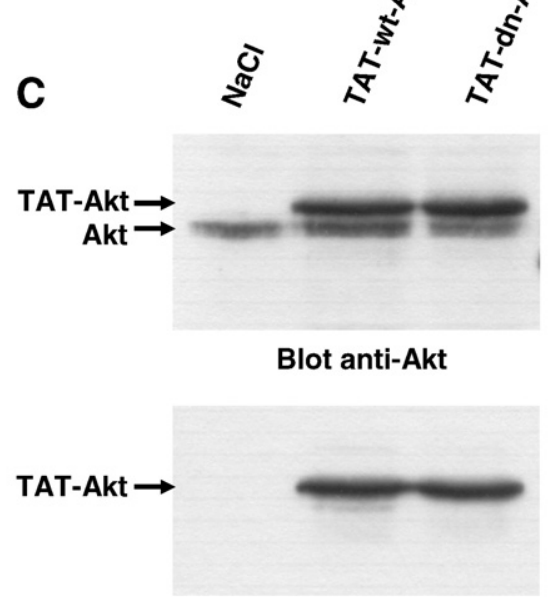

D

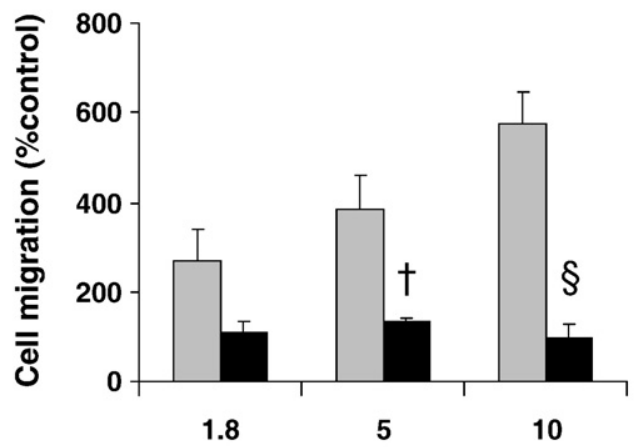

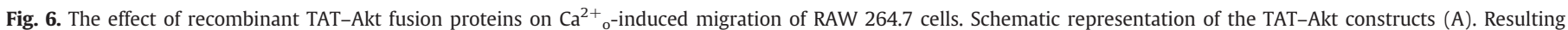

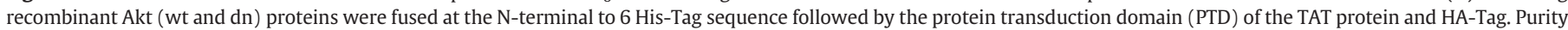

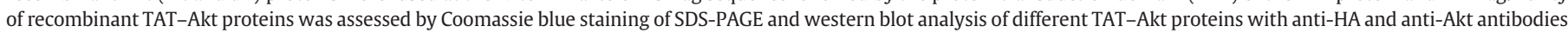

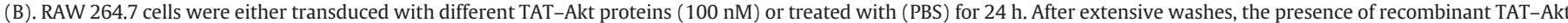

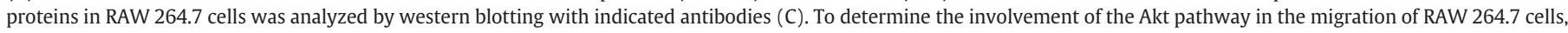

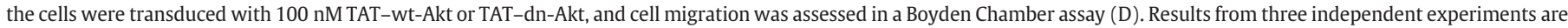
shown. Data were analyzed by $t$-test analysis, $\dagger, p<0.05$ and $\S, p<0.01$ : TAT-wt-Akt- vs. TAT-dn-Akt-transduced cell migration at the same Ca ${ }^{2+}{ }_{0}$ concentration.

resorbing osteoclasts. Clearly, these questions need to be addressed in future studies.

In conclusion, this study has demonstrated that the CaR and the PI3K/ Akt pathway are involved in the chemoattraction induced by $\mathrm{Ca}^{2+}{ }_{\mathrm{o}}$ on osteoclast precursor RAW 264.7 cells. These findings suggest that the CaR may possibly have a role in the initiation of bone remodeling in vivo.

\section{Acknowledgments}

This study was funded by the Conseil Regional de Picardie. Flow cytometry analysis was carried out at the Plateforme d'imagerie cellulaire et d'analyse des protéines (ICAP) - Université de Picardie Jules Verne (Amiens, France). We especially thank Paulo Marcelo for his technical assistance.

\section{References}

[1] Hadjidakis DJ, Androulakis II. Bone remodeling. Ann N Y Acad Sci 2006;1092: 385-96.

[2] Robling AG, Castillo AB, Turner $\mathrm{CH}$. Biomechanical and molecular regulation of bone remodeling. Annu Rev Biomed Eng 2006;8:455-98.

[3] Manolagas SC. Birth and death of bone cells: basic regulatory mechanisms and implications for the pathogenesis and treatment of osteoporosis. Endocr Rev 2000;21:115-37.

[4] Parfitt AM. Osteonal and hemi-osteonal remodeling: the spatial and temporal framework for signal traffic in adult human bone. J Cell Biochem 1994;55:273-86.
[5] Baroukh B, Cherruau M, Dobigny C, Guez D, Saffar JL. Osteoclasts differentiate from resident precursors in an in vivo model of synchronized resorption: a temporal and spatial study in rats. Bone 2000;27:627-34.

[6] Roodman GD. Advances in bone biology: the osteoclast. Endocr Rev 1996;17: 308-32.

[7] Mulari MT, Qu Q Harkonen PL, Vaananen HK. Osteoblast-like cells complete osteoclastic bone resorption and form new mineralized bone matrix in vitro. Calcif Tissue Int 2004;75:253-61.

[8] Fiedler J, Leucht F, Waltenberger J, Dehio C, Brenner RE. VEGF-A and PIGF-1 stimulate chemotactic migration of human mesenchymal progenitor cells. Biochem Biophys Res Commun 2005;334:561-8.

[9] Somerman M, Hewitt AT, Varner HH, Schiffmann E, Termine J, Reddi AH. Identification of a bone matrix-derived chemotactic factor. Calcif Tissue Int 1983;35:481-5.

[10] Mundy GR, Poser JW. Chemotactic activity of the gamma-carboxyglutamic acid containing protein in bone. Calcif Tissue Int 1983;35:164-8.

[11] Mundy GR, Varani J, Orr W, Gondek MD, Ward PA. Resorbing bone is chemotactic for monocytes. Nature 1978;275:132-5.

[12] Adams GB, Chabner KT, Alley IR, Olson DP, Szczepiorkowski ZM, Poznansky MC Kos CH, Pollak MR, Brown EM, Scadden DT. Stem cell engraftment at the endosteal niche is specified by the calcium-sensing receptor. Nature 2006;439:599-603.

[13] Olszak IT, Poznansky MC, Evans RH, Olson D, Kos C, Pollak MR, Brown EM, Scadden DT. Extracellular calcium elicits a chemokinetic response from monocytes in vitro and in vivo. J Clin Invest 2000;105:1299-305.

[14] Berger CE, Rathod H, Gillespie JI, Horrocks BR, Datta HK. Scanning electrochemical microscopy at the surface of bone-resorbing osteoclasts: evidence for steady-state disposal and intracellular functional compartmentalization of calcium. J Bone Miner Res 2001;16:2092-102.

[15] Silver IA, Murrills RJ, Etherington DJ. Microelectrode studies on the acid microenvironment beneath adherent macrophages and osteoclasts. Exp Cell Res 1988;175:266-76.

[16] Saidak Z, Brazier M, Kamel S, Mentaverri R. Agonists and allosteric modulators of the calcium sensing receptor and their therapeutic applications. Mol Pharmacol 2009. 
[17] Harir N, Pecquet C, Kerenyi M, Sonneck K, Kovacic B, Nyga R, Brevet M, Dhennin I, Gouilleux-Gruart V, Beug H, Valent P, Lassoued K, Moriggl R, Gouilleux F. Constitutive activation of Stat5 promotes its cytoplasmic localization and association with PI3-kinase in myeloid leukemias. Blood 2007:109:1678-86.

[18] Krosl J, Austin P, Beslu N, Kroon E, Humphries RK, Sauvageau G. In vitro expansion of hematopoietic stem cells by recombinant TAT-HOXB4 protein. Nat Med 2003;9: 1428-32.

[19] Saidak Z, Boudot C, Abdoune R, Petit L, Brazier M, Mentaverri R, Kamel S. Extracellular calcium promotes the migration of breast cancer cells through the activation of the calcium sensing receptor. Exp Cell Res 2009;315:2072-80.

[20] Sugimoto T, Kanatani M, Kano J, Kaji H, Tsukamoto T, Yamaguchi T, Fukase M, Chihara K. Effects of high calcium concentration on the functions and interactions of osteoblastic cells and monocytes and on the formation of osteoclast-like cells. J Bone Miner Res 1993;8:1445-52.

[21] Mentaverri R, Yano S, Chattopadhyay N, Petit L, Kifor O, Kamel S, Terwilliger EF, Brazier M, Brown EM. The calcium sensing receptor is directly involved in both osteoclast differentiation and apoptosis. Faseb J 2006;20:2562-4.

[22] Brown EM, MacLeod RJ. Extracellular calcium sensing and extracellular calcium signaling. Physiol Rev 2001;81:239-97.

[23] Chang W, Tu C, Chen TH, Bikle D, Shoback D. The extracellular calcium-sensing receptor (CaSR) is a critical modulator of skeletal development. Sci Signal 2008;1: ra1.

[24] Kameda T, Mano H, Yamada Y, Takai H, Amizuka N, Kobori M, Izumi N, Kawashima H, Ozawa H, Ikeda K, Kameda A, Hakeda Y, Kumegawa M. Calcium-sensing receptor in mature osteoclasts, which are bone resorbing cells. Biochem Biophys Res Commun 1998;245:419-22.

[25] Riccardi D, Lee WS, Lee K, Segre GV, Brown EM, Hebert SC. Localization of the extracellular $\mathrm{Ca}(2+)$-sensing receptor and $\mathrm{PTH} / \mathrm{PTHrP}$ receptor in rat kidney. Am J Physiol 1996;271:F951-6.

[26] Riccardi D, Park J, Lee WS, Gamba G, Brown EM, Hebert SC. Cloning and functional expression of a rat kidney extracellular calcium/polyvalent cation-sensing receptor. Proc Natl Acad Sci U S A 1995;92:131-5.

[27] Chattopadhyay N, Ye C, Singh DP, Kifor O, Vassilev PM, Shinohara T, Chylack Jr LT, Brown EM. Expression of extracellular calcium-sensing receptor by human lens epithelial cells. Biochem Biophys Res Commun 1997;233:801-5.

[28] Ray JM, Squires PE, Curtis SB, Meloche MR, Buchan AM. Expression of the calciumsensing receptor on human antral gastrin cells in culture. J Clin Invest 1997;99: 2328-33.

[29] Kanatani M, Sugimoto T, Kanzawa M, Yano S, Chihara K. High extracellular calcium inhibits osteoclast-like cell formation by directly acting on the calcium-sensing receptor existing in osteoclast precursor cells. Biochem Biophys Res Commun 1999;261:144-8.

[30] Handlogten ME, Huang C, Shiraishi N, Awata H, Miller RT. The Ca2+-sensing receptor activates cytosolic phospholipase A2 via a Gqalpha -dependent ERKindependent pathway. J Biol Chem 2001;276:13941-8.
[31] Chattopadhyay N, Yano S, Tfelt-Hansen J, Rooney P, Kanuparthi D, Bandyopadhyay S, Ren X, Terwilliger E, Brown EM. Mitogenic action of calcium-sensing receptor on rat calvarial osteoblasts. Endocrinology 2004;145:3451-62.

[32] Yamaguchi T, Chattopadhyay N, Kifor O, Sanders JL, Brown EM. Activation of p42/44 and p38 mitogen-activated protein kinases by extracellular calciumsensing receptor agonists induces mitogenic responses in the mouse osteoblastic MC3T3-E1 cell line. Biochem Biophys Res Commun 2000;279:363-8.

[33] de Jesus Ferreira MC, Helies-Toussaint C, Imbert-Teboul M, Bailly C, Bellanger AC, Chabardes D. Co-expression of a Ca2 +-inhibitable adenylyl cyclase and of a Ca2+sensing receptor in the cortical thick ascending limb cell of the rat kidney. Inhibition of hormone-dependent cAMP accumulation by extracellular $\mathrm{Ca} 2+$. J Biol Chem 1998;273:15192-202.

[34] Corbetta S, Lania A, Filopanti M, Vicentini L, Ballare E, Spada A. Mitogen-activated protein kinase cascade in human normal and tumoral parathyroid cells. J Clin Endocrinol Metab 2002;87:2201-5.

[35] Tu CL, Chang W, Xie Z, Bikle DD. Inactivation of the calcium sensing receptor inhibits E-cadherin-mediated cell-cell adhesion and calcium-induced differentiation in human epidermal keratinocytes. J Biol Chem 2008;283:3519-28.

[36] Bilderback TR, Lee F, Auersperg N, Rodland KD. Phosphatidylinositol 3-kinasedependent, MEK- independent proliferation in response to CaR activation. Am J Physiol Cell Physiol 2002;283:C282-8.

[37] Tfelt-Hansen J, Chattopadhyay N, Yano S, Kanuparthi D, Rooney P, Schwarz P. Brown EM. Calcium-sensing receptor induces proliferation through p38 mitogenactivated protein kinase and phosphatidylinositol 3-kinase but not extracellularly regulated kinase in a model of humoral hypercalcemia of malignancy. Endocrinology 2004;145:1211-7.

[38] Liu KP, Russo AF, Hsiung SC, Adlersberg M, Franke TF, Gershon MD, Tamir H. Calcium receptor-induced serotonin secretion by parafollicular cells: role of phosphatidylinositol 3-kinase-dependent signal transduction pathways. J Neurosci 2003;23:2049-57.

[39] Munugalavadla V, Vemula S, Sims EC, Krishnan S, Chen S, Yan J, Li H, Niziolek PJ, Takemoto C, Robling AG, Yang FC, Kapur R. The p85alpha subunit of class IA phosphatidylinositol 3-kinase regulates the expression of multiple genes involved in osteoclast maturation and migration. Mol Cell Biol 2008;28:7182-98.

[40] Pilkington MF, Sims SM, Dixon SJ. Wortmannin inhibits spreading and chemotaxis of rat osteoclasts in vitro. J Bone Miner Res 1998;13:688-94.

[41] Godwin SL, Soltoff SP. Extracellular calcium and platelet-derived growth factor promote receptor-mediated chemotaxis in osteoblasts through different signaling pathways. J Biol Chem 1997;272:11307-12.

[42] Kundra V, Escobedo JA, Kazlauskas A, Kim HK, Rhee SG, Williams LT, Zetter BR. Regulation of chemotaxis by the platelet-derived growth factor receptor-beta. Nature 1994;367:474-6.

[43] Martinez-Reina J, Garcia-Aznar JM, Dominguez J, Doblare M. On the role of bone damage in calcium homeostasis. J Theor Biol 2008;254:704-12.

[44] Garner SC, Pi M, Tu Q, Quarles LD. Rickets in cation-sensing receptor-deficient mice: an unexpected skeletal phenotype. Endocrinology 2001;142:3996-4005. 